\title{
Literature Review of Carbon Finance and Low Carbon Economy for Constructing Low Carbon Society in China
}

\author{
Shihong Zeng, Shuai Zhang \\ Economics Management School, Beijing University of Technology, Beijing, China. \\ Email: zengshihong2000@yahoo.com.cn
}

Received January $3^{\text {rd }}, 2011$; revised January 25 ${ }^{\text {th }}, 2011$; accepted January $28^{\text {th }}, 2011$.

\begin{abstract}
The purpose of the research is that China develops low-carbon economy and strengthens low-carbon economy research by learning other countries experiences, which literatures in the papers introduced. The principal results of the paper is that the paper done up right literatures review of carbon finance and low carbon economy. The major contribution is that the paper finds that China is facing the challenges of the global carbon finance problem and the lack of its pricing power. The conclusions is that we need to increase our academic research on carbon finance to solve China's lagging in carbon finance construction and knows how to construct development system.
\end{abstract}

Keywords: Low-Carbon Economy, Carbon Finance, Literature Review

\section{Introduction}

Low-carbon economy mostly linked global climate change and energy conservation together. People have created a huge supply of funds and financial flow mechanism based on the low-carbon economy. China is making great efforts to develop low-carbon economy, and China is one of the countries which have abundant resources of "carbon finance". This determines that China must have the voice on the carbon finance market and the right to price the carbon financial products. Therefore the development of carbon financial system, to promote "low-carbon economy" research which based on China's national conditions is very important. This article firstly introduced some articles about the low carbon economy at home and abroad, and gives the definition of a low carbon economy. Then introduced some articles related to the carbon finance. It is hope that this article can provide assistance for scholars to make further study.

With the gradual warming of global climate as well as conventional energy depletion and other issues constantly being realized, people started to focus on lowcarbon model of economic development. The low-carbon economy rise from the change of the international climate policy, specifically, involves two significant international conventions: the 1992 "United Nations Framework Convention on Climate Change," and the 1997
"Kyoto Protocol." Low-carbon economy, on the surface has more to do with global climate change and energy conservation, but in practice a huge supply of funds and financial flow mechanism has been formed.

As for the real economy of low-carbon model development, it also has the characteristics of financial capital flows. "Kyoto Protocol" designed three carbon emission reduction market mechanisms, since different business carbon emissions and carbon abatement costs , the enterprise which has more emissions rights can sell the excess to those enterprises which have shortage of emission rights in order to obtain benefits. Carbon emissions rights which have market value of liquidity as well as general goods can be traded in the market.

Financial institutions develop a number of carbonbased insurance products, derivatives and structured products in order to manage and transfer risks and costs of carbon emissions and get more sustainable profits. So carbon emissions right has become a financial instrument, the price is becoming more and more decided by financial markets. More and more financial capital is involved in low-carbon economy, so it comes from the carbon emission rights market and the low-carbon economic development turns into a carrier of financial tool for innovation.

Since the development of carbon finance is based on 
low-carbon economy, the activities of financial markets and financial policies related to the development of a low carbon economy can be collectively regarded as "carbon finance." "Carbon finance” includes all financial transactions which reduce carbon emissions, carbon emissions rights and its derivatives transactions, investment or speculative activities, the investment and financing activities on low-carbon energy projects and the associated security, advisory services and related activities.

China is one of a small number of countries which have abundant "carbon finance" resources. According to the data released by the State Development and Reform Commission, China ended in March 2010 had approved 2369 CDM cooperation projects ${ }^{1}$. If China wants to continue to maintain rapid sustainable economic development in future, the right to speak in carbon finance market can not be lost .China must have the power to price the carbon finance products. Therefore, promoting lowcarbon technologies, capital flows and accumulation to develop low carbon economic based on China's national conditions is particularly urgent.

We hope that this article can provide some assistance for scholars to make further study.

The structure of this manuscript is arranged as follows: the II section of this article reviews some articles about the low carbon economy at home and abroad; the III section of this article reviews some articles about the carbon finance at home and abroad; the IV section of this article conclude the paper.

\section{Literature Review on Low Carbon Economy}

The following documents analyze the need of implementation of the low carbon economy.

1992 "United Nations Framework Convention on Climate Change," and the 1997 "Kyoto Protocol", pushes this new low-carbon economy model of economic development directly to the stage of history.

References [1-3] think that the essence of a low carbon economy is problems on energy efficiency and clean energy structure and the core is the energy technology innovation and system innovation, the goal is to mitigate climate change and promote human sustainable development. We spare no effort to minimize greenhouse gas emissions to slow global climate change and to realize clean sustainable economic and social development through technique and system innovation as long as without prejudice to economic and social development.

Reference [4] proposed that the expansion of low-cost investment in growth-oriented economy for the healthy development of China is unsustainable, it is necessary to

\footnotetext{
${ }^{1}$ The data come from

http://cdm.cchina.gov.cn/WebSite/CDM/UpFile/File2418.doc.
}

develop and implement green development strategy, establish the environmental protection, DC, to promote low carbon economic development, in order to solve the China's economic growth mode transformation lag issues.

Reference [5] think that, while economic growth remains the primary consideration by Governments, but climate change is a key factor which urgently need to be addressed on the road of economic development for all countries. Protection of the environment, especially the control of greenhouse gas (GHG) emissions has become a standard of quality of national economic growth.

Reference [6] analyzed from China's concrete situation. He thinks that developing low carbon economy must be taken to address climate change to promote China's economic growth and energy security.

According to the above summary, climate change is becoming a universal concern of the international key issues, low-carbon way of economic development has became the world attention, the environment is even a standard of measuring economic growth quality. China should regard developing a low carbon economy as an opportunity to change the "three high one low" growth, promote economic restructuring and green development. Low carbon economy to promote sustainable economic development is important for economic restructuring. But how is the availability of controlling carbon emissions? The following documents are related to the study of the implementation of low-carbon economy.

2003 UK Energy White Paper "Our energy future: creating a low carbon economy" came up with "low-carbon economy" concept in the first time. Then the country and abroad had studied in the implementation of low carbon economy.

Reference [7] searched in the related technical feasibility of the UK housing stock by substantially reducing emissions of carbon dioxide. They concluded that the use of existing technology to the middle of this century can reduce baseline emissions in 1990 to $80 \%$.

Reference [8] identified related factors which impact the changes in emissions of pollutants through long-term climate stabilization scenarios for research: the carbon intensity, energy efficiency and economic activities. They pointed that we need to speed up intensity in improving comprehensive energy and decline rate should increased 2-3 times based on the past 40 years in order to achieve $60-80 \%$ reduction of carbon emission reduction targets.

Reference [9] designed a low carbon economy for the local level of the Japanese government to control greenhouse gas emissions in the long-term approach through empirical research in Shiga. Here's how: First, develop a method to quantitatively estimate in the county's indus- 
trial, commercial, residential and transportation of carbon dioxide emissions and forecast the future of these units of carbon dioxide emissions. On this basis, then quantitatively design line of low-carbon economy: 1) Maintained the county's $1.6 \%$ annual GDP growth, so that carbon dioxide emissions reduce by $30-50 \%$ by 2030 baseline in 1990. 2) To achieve the intended emission reductions must adjust the socio-economic structure and develop the new technology initiatives. 3) Adopt innovative measures at the county level, including: land planning, promoting renewable energy and lifestyle changes.

Reference [5] thinks that the protection of the environment, particularly greenhouse gas (GHG) emissions have become an indicator of quality of economic growth. As the international community has had a global consensus on carbon price, so some countries have developed strategies for economic development in low-carbon leading. A Masidaer project in Abu Dhabi, United Arab Emirates, is developing a renewable energy and sustainable development of broad stone technology, low-carbon economy for the future development of skills, knowledge institutions and the necessary capital. In addition, the aims of the Masidaer project is to establish a carbon neutral, zero waste city in the world and taking efforts to develop carbon capture and storage project.

Reference [10] explored the background of low-carbon economy, analyzed the China's development path and methods of low-carbon economy. China can control carbon emissions and develop low carbon economy through the development of low carbon industry in China, low-carbon agriculture, low-carbon industry, carbon sequestration and carbon reduction cities and other feasible ways.

There is no international unity on the definition of low-carbon economy, combined with the documents above we can defined it as: it is a win-win economic development patterns that under the guidance of the concept of sustainable development, through technical innovation, new energy development, industrial restructuring, system innovation and other means to reduce coal and oil consumption of high-carbon energy, reduce greenhouse gas emissions, achieve economic and social development and ecological environment protection as much as possible. Low-carbon economy, in essence, is the efficient use of energy, clean energy development, the creation of green GDP, the core is the energy technology and carbon emission reduction technology innovation, industrial structure and system innovation and the concept of human survival and development of fundamental change.

\section{Carbon Finance Literature Review}

Carbon finance is built on the basis of a low carbon economy, financial market activities which develop a low carbon economy and the related policy can be referred to as "carbon finance." So far, main research about financial carbon finance at home and abroad is:

Reference [11] proposed the establishment of carbon credit financing is an effective measure to control greenhouse gas emissions.

Reference [12] studied Guyana (Latin America) of concrete cases, analyze the economic feasibility of carbon offset projects through cost-benefit analysis and carbon emissions in the simulation model. Analysis showed that when the price of $\$ 0.23 / \mathrm{tC}$ carbon sinks, the large-scale commercial forest harvesting and forest protection benefit breakeven.

Reference [13] study is based on national planning and development department by the input-output tables, using the input-output decomposition technique analyze four aspects of measures to reduce the effect of carbon equivalent, which is four: fuel mix effect (due to a change in the emissions of fuel mix changes), structural effect (no carbon tax and carbon tax case, changes in emissions), the impact of final demand (final demand change on the impact of changes in emissions), Combined (mixed fuel, structure and final demand of these three aspects of the interaction effect). Out the final conclusion is: when the carbon tax is $\$ 50 / \mathrm{tC}$, the energy tax is $\$ 1.0 / \mathrm{MBtu}$, you can control carbon emissions.

Reference [14] the United States formulated trade policy to control carbon emissions, the establishment of a well-designed carbon trading market to develop carbon price will be a major factor for enterprises to reduce costs and promote the innovation. In the establishment of carbon trading market, we must also formulate relevant supporting policies, such as incentives related to such, only in this way can be more effectively prompted the U.S. transition to a low carbon economy.

Reference [15] the Indian government plans to take home solar power plan to give light to 78 million rural families which still use kerosene for lighting for the lack of transmission equipment. This program can not only bring light to rural families, but also can effectively reduce greenhouse gas emissions. In the clean development mechanism, the scheme will bring the benefits by calculating because of greenhouse gas emission reductions. When the $\$ 10 / \mathrm{tC}$, give each family reduced by $19 \%$ of the cost.

Reference [16] from a theoretical point of view, the Clean Development Mechanism the scale of the reduction of greenhouse gas emissions for developing countries, even in government financial support to reduce the case, the reduction power is adequate, the project's crediting process is effective inter-of. However, the effect of the clean development mechanism must also be larger in developing countries results in carbon emissions to be 
verified. Articles by China, for example, of the clean development mechanism to promote renewable energy development in China to play a role, and how the international carbon finance can best be used to help reduce emissions in developing countries is analyzed.

Reference [17] thinks that carbon emission reduction and economic growth can both be obtained. China's carbon emissions trading market is a huge global financial market space, we should speed up the carbon financial product innovation, low-carbon economy and a win-win financial innovation.

References [18] analyzed the main function of carbon finance in response to climate change as well as the major obstacle in development of China's carbon finance and propose China's carbon finance strategy to deal with the obstacles.

Reference [19] introduced operation on the international carbon market. They proposed eight kinds of carbon financial innovation model, namely: banks type Carbon Fund financial products to yield the right of CERs as a pledge of loans, financial leasing, factoring, financial products of carbon trust, private equity, carbon asset securitization and insurance, carbon trading.

Reference [20] summarizes the development of the international financial community about the major experiences of low-carbon economy; combined with the Industrial Bank case based on low-carbon economic development on the demand for green finance, explore effective ways to push to speed up China's green financial innovations.

The study above analyzed the specific situation of implement carbon finance by some specific case . whether it is carbon offset, carbon neutral, carbon taxes and other measures have effectively reduced carbon emissions, it has brought benefits to countries which implement related projects and promote a low-carbon economy of the development process. The study of Chinese and foreign literature provide a reference for study of low carbon economic development and the establishment of carbon finance system, but the disadvantage of Chinese and foreign literature is that there is only description or study about the low-carbon economy and the development of carbon finance in foreign countries, not from the national conditions of China to find out good ways to solve a serious related problems.

China's current carbon trading is still in a "farmers market" stage, is only focused on the specific case of carbon trading in a project. China has not established a complete and unified platform for carbon trading and carbon sound financial system. China's greenhouse gas emissions and emissions trading cases in years, but scattered in various cities across China and various industries are basically dealing with overseas buyers by the com- pany in direct consultation and negotiation, the degree of information transparency is not enough. Because of the scattering of non-public market conditions, China's participation in carbon emission trading companies are often in a weak position in negotiations, resulting in the final transaction price is far from the international market price. So long continues, will inevitably result in situation that now sell it low and buy it high in future. "Carbon finance and carbon trading is just like two legs. Without the support of carbon finance, carbon trading in China will not only lose their pricing power, and will once again lose the opportunity of financial innovation."

Through analysis of existing literature, despite domestic commercial banks take the action of carbon finance, but did not go deep into the core of carbon finance-related part of the carbon finance project development. They are not yet familiar with carbon finance development, operation mode, the transaction rules, and are lack of deep understanding of relevant expertise on the CDM (clean development mechanism), the ability of investment-related projects in this area is inadequate. Not only is lack of maturity in the domestic carbon trading scheme, carbon trading and carbon trading platform sites, and no securities, such as carbon, carbon swaps, futures and other carbon-carbon derivatives products of financial innovation.It is hard to compete with the international financial institutions.China is facing challenges that the problem of global carbon finance and the lack of its pricing power.

For financial development in China lags behind the current status of carbon, we need to increase our academic research on carbon finance to solve China's lagging behind in carbon finance construction and know how to construct development system and other related issues.

\section{Conclusions}

The major contribution of the paper is that the paper finds that China is facing the challenges of the global carbon finance problem and the lack of its pricing power. The conclusion is that we need to increase our academic research on carbon finance to solve China's lagging in carbon finance construction and know how to construct development system.

\section{Acknowledgements}

The research was achievements of the current stage of 2011 Beijing philosophy \& Social Science research program (2011 Beijing Education Committee key project): a subtopic of study on financial development in Beijing based on low carbon economy. The authors thank Reviewer's opinions. 


\section{REFERENCES}

[1] G. Y. Zhuang, "The Way of China's Low-Carbon Economy Development and Analysis of its Potential," International Technical and Economic Research, No. 3, 2005, pp. 79-87.

[2] Y. Fu, Y. H. Ma, Y. C. Liu and W. Y. Niu, "Low-Carbon Economic Development Mode," Chinese Population Resources and Environment, No. 3, 2008, pp. 14-19.

[3] C. J. Liu and B. M. Feng, "The Revelation of Low-Carbon Economy on the Construction of Wuhan City Circle 'Two Type Society' in China,” Chinese Population Resources and Environment, No. 5, 2009, pp. 16-21.

[4] N. Xiag and F. Xia, "Low-Carbon Economy and Green Development Strategy-The Thought for the First in Hainan to Establish the First National Environmental Protection,” China Soft Science, No. 10, 2009, pp. 13-22.

[5] S. Nader, "Paths to a Low-Carbon Economy-The Masdar Example,” Energy Procedia, Vol. 1, No. 1, 2009, pp. 3951-3958. doi:10.1016/j.egypro.2009.02.199

[6] B. Jiang, Z. Q. Sun and M. Q. Liu, "China's Energy DeVelopment Strategy under the Low-Carbon Economy," Energy, In Press, Corrected Proof, Available online 4 February 2010.

[7] D. Johnston, R. Lowe and M. Bell, “An Exploration of the Technical Feasibility of Achieving $\mathrm{CO}_{2}$ Emission Reductions in Excess of $60 \%$ within the UK Housing Stock by the Year 2050," Energy Policy, Vol. 33, No. 13, 2005, pp. 1643-1659. doi:10.1016/j.enpol.2004.02.003

[8] R. Kawase, Y. Matsuoka and J. Fujino, "Decomposition analysis of $\mathrm{CO}_{2}$ Emission in Long-Term Climate StabiliZation Scenarios,” Energy Policy, Vol. 34, No. 15, 2006, pp. 2113-2122. doi:10.1016/j.enpol.2005.02.005

[9] K. Shimada, Y. Tanaka, K. Gomi and Y. Matsuoka, "Developing a Long-Term Local Society Design Methodology towards a Low-Carbon Economy: An application to Shiga Prefecture in Japan,” Energy Policy, Vol. 35, No. 9, 2007, pp. 4688-4703. doi:10.1016/j.enpol.2007.03.025

[10] J. Q. Bao, Y. Miao and F. Chen, "Low-Carbon Economy: a New Mode of Economic Development of Human Transformation," China Industrial Economy, No. 4, 2008, pp. 153-160.
[11] John, "How Carbon Credits could Drive the Emergence of Renewable Energies,” Energy Policy, Vol. 36, No. 10, 2008, pp. 3633-3639. doi:10.1016/j.enpol.2008.05.033

[12] T. Osborne and C. Kiker, "Carbon Offsets as an Economic Alternative to Large-Scale Logging: A Case Study in Guyana,” Ecological Economics, Vol. 52, No. 4, 2005, pp. 481- 496. doi:10.1016/j.ecolecon.2004.06.003

[13] K. Siriwardena, P. D. C. Wijayatunga, W. J. L. S. Fernando, R. M. Shrestha and R. A. Attalage, "Economy Wide Emission Impacts of Carbon and Energy Tax in Electricity Supply Industry: A Case Study on Sri Lanka," Energy Conversion and Management, Vol. 48, No. 7, 2007, pp. 1975-1982. doi:10.1016/j.enconman.2007.01.030

[14] J. Peace and T. Juliani, “The Coming Carbon Market and Its Impact on the American Economy," Policy and Society, Vol. 27, No. 4, 2009, pp. 305-316. doi:10.1016/j.polsoc.2009.01.002

[15] Chaurey and T. C. Kandpal, "Carbon Abatement Potential of Solar Home Systems in India and Their Cost Reduction Due to Carbon Finance," Energy Policy, Vol. 37, No. 1, 2009, pp. 115-125. doi:10.1016/j.enpol.2008.07.038

[16] J. I. Lewis, "The Evolving Role of Carbon Finance in Promoting Renewable Energy Development in China," Energy Policy, In Press, Corrected Proof, Available online 6 February 2010.

[17] W. F. Ren, "Low-Carbon Economy and Environment of Financial Innovation,” Shanghai Economic Research, No. 3, 2008, pp. 38-42.

[18] Y. Y. Wu, "The Development of China's Carbon Finance and Carbon Finance Mechanism Innovation Strategy," Shanghai Finance, No. 10, 2009 , pp. 23-29.

[19] L. Z. Wang and Y. Song, "Discussion on Carbon Trading in Financial Innovation and Risk Prevention,” Journal of Tianjin University of Finance and Economics, No. 6, 2009, pp. 30-34.

[20] L. R. Yan, Y. W. Lai, B. Zhang and Z. L. Li, "Boosting Low-Carbon Economic Development of the Green Financial Innovations,” Fujian Finance, No. 12, 2009, pp. 4-8. 